focus on German Studies.

https://journals.uc.edu/index.php/fogs

(ISSN 1076-5697)

Issue 27 (2020)

Book Review

Europa und Erinnerung. Erinnerungsorte und Medien im 19. und 20. Jahrhundert

by Alexandra Przyrembel and Claudia Scheel, transcript Verlag, 2019. 260 pp. 21.99€

Anna Guboglo

Institute for East European History, University of Vienna

How to Cite: Guboglo, Anna. "Book Review: Europa und Erinnerung. Erinnerungsorte und Medien im 19. und 20. Jahrhundert edited by Alexandra Przyrembel and Claudia Scheel”. focus on German Studies 27: Spielformen des Authentischen, no. 27, 2020, pp. 77-82. doi: 10.34314/FOGS2020.00006. 


\section{Europa und Erinnerung. Erinnerungsorte und Medien im 19. und 20. Jahrhundert} by Alexandra Przyrembel and Claudia Scheel, transcript Verlag, 2019. 260 pp. Anna Guboglo

The collection of twelve essays edited by Alexandra Przyrembel and Claudia Scheel of the University of Hagen is a massive contribution to the fields of Heritage Studies and global history through its strong focus on, yet novel interpretation of the concept lieux de mémoire. Going beyond Pierre Nora's conceptualization of the sites of memory (not to be confused with memorial sites), the book transgresses its material and topographical dimensions, turning moments of collective memory into veritable sites of memory. Furthermore, for the authors the sites represent an instrument for approaching the history of nineteenth and twentieth century conflicts.

The introductory chapter puts forward the common thread of all of the book's essays, addressing the issue of the duality object/its representation. The role of media, specifically of photography, in the formation of collective memory is researched through the prism of the 'iconic turn', in the sense of the contemporary shift of focus from the photograph as a document to its instrumentalization and towards a critical analysis of the overwhelming circulation of information through photographs. Some other methodological milestones reflected in this book are the introduction of Reception History and of the global approach into the study of objects, events or places considered to be sites of memory. Thus, the essential question tackled throughout the book is whether there is a common European memory, and how it came into existence.

This critical attitude extends to all 'memory media', such as films and press, and deconstructs the importance of imagined common sites of memory to the formation of historical and national identity (24). With this attitude in mind, the book is divided into three 
parts: pre-War master narratives, representations of violence, and post-War memory culture. At first sight, the articles in the book seem to have different foci (Claudia Scheel's essay on nineteenth-century world exhibitions, Wolfgang Kruse's research on the legacy of the fall of the Bastille and that on August 1914 momentum, Arthur Schegelmilch's portrayal of Wallenstein's public image and Lucas Hardt's analysis of the filmography related to the French Foreign Legion) -however, they use similar methodologies. Claudia Scheel's essay argues that for instance the 1867 Paris Exhibition assumed the mission of inventorying the world, thus illustrating the faith in progress that dominated nineteenth century mentality. Consequently, exhibitions were sites where modernity was exhibited and experienced, sites which allowed the creation of transnationally shared experiences.

Although the storming of the Bastille is associated with a milestone in the history of not only French, but also European and worldwide democratization, its symbolism is multilayered: It represents the revolutionary tradition of French modernity, the despotism of the absolutist regime, and the threshold dividing the old world from the new one. Wolfgang Kruse's research on the remembrance of the Bohemian commander Albrecht von Wallenstein, killed due to accusation of treason through the Kaiser's decree in 1634, is emphasizing the importance of celebrations and rituals of remembrance and the immortalization through the physical perpetuation of the site's materiality in the form of monuments.

The second essay by Wolfgang Kruse is a rather intricate account of people's expectations and hopes in the summer of 1914. The author illustrates how August 1914 can be considered a memory site and discusses its various layers of meaning: August 1914 was associated by some with the beginning of women's emancipation, by others with the maturation of the 'lost generation' with its Weltanschauung, and by the majority with the beginning of a continuous wartime. The reader is given to understand that, while as a site of 
memory August 1914 manifested pan-European aspects (the enthusiasm with which the peoples of Europe welcomed the war), it changes the angle of view within various European cultures of remembrance. On a separate note, the study displays how the propagandistic use of famous photographs, such as that of Hitler on $2^{\text {nd }}$ of August 1914 in Munich, influenced the course of history by entering the public memory and turning the images into a myth.

As the second part advances further into the twentieth century, it centers on the visual memory of violence created by photographic means. The essays on the visualization of Ottoman anti-Armenian violence by Alexandra Przyrembel and that on the Second World War photograph of a boy from the Warsaw ghetto by Florian Gregor revolve around the reception history of photographs, building on the idea that photographs are the formants of visual memory. Both essays demonstrate the universality of the portrayed victims, and the great degree of empathy caused by the circulation of the photographs. While the photograph of the boy from the Warsaw ghetto is a deeply engraved cultural projection of a concrete site of memory - the ghetto - the Anatolian photographs shaped non-specific 'Oriental' sites of memory, as numerous as the surroundings of the photographs depicting genocide victims. Alexandra Przyrembel's study of the September 1941 mass killing at Babij Jar as a site of memory illustrates the problem of public memory depending on the visual with great accuracy. To this tragedy, there are few survivors, no photographs, and very few culprits known. A common theme of the essays is the assumed modern character of violence. Violence gained a civilized aura primarily through the dehumanization of the victims: a phenomenon counteracted by the circulation of visual representations. Catherine Davies's account of the overwhelming publicity of the process against Adolf Eichmann argues that increased interest and media presence may turn such an event into a "shared European site of memory" (175).

The third part investigates aspects of the post-War global visual memory with the 
essays on Yevgeny Khaldei’s photograph of the red flag over the Reichstag (Saskia Geisler), on the case of the Hamburg First World War memorial at Dammtor (Arndt Neumann) and on the 1954 photograph of the mushroom cloud after the atomic explosion of the American Bravo (Sibylle Marti). The image of the atomic mushroom became iconic and circulated globally in the time of the Cold War nuclear race. The ambivalence of the image inspiring both fear and the perception of the technical advancement of the United States is discussed by Sibylle Marti along with the semiotic significance of widespread images and symbols. In the same vein, Arndt Neumann shows that the media-induced image of the Hamburg First World War monument became more important than its original meaning in the past decades. The reception history of the monument characterizes post-War German society as rejective of any symbol of the war discourse introduced by the authoritarian regime, implying a generational conflict. Taken more broadly, the changed attitude to war and violence in general appears to be a pan-European phenomenon of this generation.

Saskia Geisler focuses on Yevgeny Khaldei’s biography in order to explain his work and points out his aim to primarily portray the superiority of the Soviet state rather than specific people. She also briefly addresses the staging of the photograph and of the photoshoot. As a critique of this essay, but also of the intention of the entire book to discuss the processing or manipulation of photographs, one might say that both lack a closer look at the importance of authenticity in the value attributed to a photograph, and the viewer's expectation of spontaneity as opposed to staging.

Another potentially beneficial contribution to this discussion would be the arthistorical analysis of visual sources, since the authors mostly focus on iconographic analyses. All twelve essays differ stylistically in accordance to their sources and their goals, ranging in their focus from political histories to cultural narratives, but manage to create an ensemble of scholarly texts unified by skillful zooming out of microhistorical accounts in order to 
display an image of a common European memory culture. This laudable consistency is achieved by applying the transnational approach to the history of information flows of the nineteenth and twentieth centuries.

Far from a monolithic work, this collection of essays manages to freshen up the concept of the site of memory, stripping it to the meaning of an associative relation between an object and an event. The contributions demonstrate that remembrance can come in many different shapes and forms, be it oral history, ceremonial commemoration, or even silencing, and that all sites of memory went through a long evolution of changing symbolism until reaching their contemporary configurations. 